\title{
An Evaluative Review of School Accreditation Implementation Program in Indonesian Contexts
}

\author{
Sri Haryati ${ }^{1}$ \\ ${ }^{1}$ Tidar University Magelang, Central Java Indonesia, Indonesia \\ Correspondence: Sri Haryati, Faculty of Education, Tidar University of Magelang, Indonesia. Tel: \\ 62-813-2587-7915. E-mail: sriharyati717@yahoo.com
}

Received: February 8, 2014 Accepted: March 11, 2014 Online Published: April 29, 2014

doi:10.5539/ies.v7n5p138 URL: http://dx.doi.org/10.5539/ies.v7n5p138

\begin{abstract}
This paper critically reviews and evaluates the implementation of School Accreditation Program for the period of 2013 with a particular reference to Central Java Schools, consisting of Kindergarten (TK) Elementary School (SD), Junior High School (SMP) and Senior High School (SMA) (Note 1). The aim of the review is to see to what extent they can comply with the 'Education for All' (EFA) Program as expressed in World Summit (2000) resulting in a Millennium Declaration known as "Millennium Development Goals (MDG). The research setting involved Central Java, covering 35 regencies as the sample consisting of 1,985 schools as the target and realized $1,972(99 \%)$ schools accredited. It turned out that there were technical problems at schools of all levels, ranging from pre-accreditation, accreditation to post accreditation in need of special attention by involved parties for better improvement of the program implementation.
\end{abstract}

Keywords: accreditation, school, competence, educational standards

\section{Introduction}

\subsection{Background}

Obsessed by the 'Millennium Development Goals' (MDG) for improved services in education, the Government of the Republic of Indonesia has done various efforts at the central level in the form of educational policies, and at the regional levels in the form of practical procedures of implementation of School Accreditation Program (SAP) in the hope that all schools, ranging from Elementary Schools (SD/MI), Junior Senior High Schools (SMP/MTs) to Senior High Schools (SMA/MA/SMK) are operationally accredited in compliance with the requirements as set in the standards of quality education.

With respect to Education for All (EFA), the first target is that in 2015 all children, male and female alike, wherever, must be able to complete basic education (SD). Secondly, referring to the past (2005) gender equality and woman empowerment had to be thoroughly dealt with, namely there started to be no gender discrimination in basic and high school education, and no later than 2015 at all levels of education shall comply with accordingly. For this, the Government issued Presidential Decree (Instruction) No 9 Year 2009 to eliminate gender discrimination in the National Development as an attempt to improve the implementation of the gender equality and justice program. Therefore each region throughout Indonesia has been assigned to formulate a short-term development plan (RPJMD) 2010-2015, along with the annual work plan (RKPD), and with respect to education, the regional strategic plan for education along with its plans of actions.

\subsubsection{Basic Policies on School Accreditation}

A number of laws stipulating the school accreditation among others include (1) Law No. 20/2003 on National Education System, (2) Government Regulation No. 19/2005 on National Education Standards, (3) Education Ministerial Decree No. 59/2012 on National School Accreditation Board, (4) Central Java Governor's Decree No 8/2013 on Provincial School Accreditation Board (2013-2018) along with the Governor's Decree of Establishment of Provincial School Accreditation Board No. 420/23/2013 for the period of 2013-2018. In particular, it is stipulated (National Education System Law No 20/2003) that:

1) Accreditation is performed to specify whether a particular unit of education is eligible and feasible for operation as formal and non-formal education in each level and type; 
2) It is performed by an independent organization/institution with guaranteed public accountability;

3) It is performed on the basis of open criteria.

The stipulation is further outlined in The Government Regulation No. 19/2005, Article (2), stating that:

1) Quality control and assurance in accordance with National Education Standards (SNP) shall be undertaken in three integrated programs, namely evaluation, accreditation and certification;

2) Quality assurance aims at protecting the community against malpractice of education in order to have services and outcomes of education as set by the educational providers;

3) Education standardization is significant as a guide to the direction of national education with flexibility and freedom of implementation:

4) SNP shall be made a reference to by education providers as empowerment of initiatives and creativity in achievement of minimally required standards;

5) SNP shall be the basis for the formulation of criteria and instruments of accreditation with a comprehensive, transparent, objective and just form of public accountability

Furthermore, SNP is elaborated in eight standards for Elementary School (SD), Junior High School (SMP), and Senior High School (SMA), and in four standards for Kindergarten(TK). The eight standards for SD, SMP and SMA include:

1) Standard of Contents-Ministerial regulation for education No. $22 / 2006$

2) Standard of Process-Ministerial regulation for education No. 41/2007

3) Standard of Graduate Competence-Ministerial regulation No. 23/2006

4) Standard of Teachers and Education Administrators-Ministerial regulation for education No. 23/2007

5) Standard of Infrastructure-Ministerial regulation for education No. 24/ 2007

6) Standard of Management-Ministerial regulation for education No. 19/2007

7) Standard of Finance - Government regulation for education No. 48/2008

8) Standard of Evaluation - Ministerial regulation for education No. 20/2007

Meanwhile, the four standards for TK include:

1) Standard of Development Achievement Level

2) Standard of Teachers and Education Administrators

3) Standard of Contents, Process, and Evaluation

4) Standard of Infrastructure, Management and Finance

For ease of implementation of the school accreditation program for each of the above education units, the National Board of School Accreditation has provided the Accreditation Instruments that have been agreed upon and validated for use by the Minister of Education of the Republic of Indonesia in the Ministerial Regulations (Permendiknas) for education No. 11/2009.

\subsubsection{Objectives and Significance of Accreditation}

Accreditation is aimed at providing information on the feasibility and eligibility of education units whether or not they have met the requirements as set by the National Standard of Education (SNP) by means of acknowledgement of the accreditation ranks in support of quality assurance for the accredited education units and the public community (shareholders). It is therefore of significance in five different ways, namely as (1) a reference for improvement of school quality and school development plan, (2) a motivator for schools to competitively, comprehensively improve educational services at regional, national or even international levels, (3) a useful feedback in efforts of empowerment of school performance in implementing the vision and missions, and (4) useful information for schools as the learning communities to gain supports from the Government, societies, and private sectors in terms of professionalism, morality, human resources and finance.

In short, the functions of accreditation include acknowledgment of eligibility and feasibility, accountability for the public as the end users whether or not their demands have been met, and improvement and development as the basis in order for all related parties to improve and develop the quality of education. 


\subsubsection{Mechanism of School Accreditation}

Provincial Board of School Accreditation (BAP-S/M) in coordination with Local Education Offices allocates the number of schools including MI, MTs and MA that will be accredited upon which to assign the school principals to register their schools for accreditation via the website http://www.ban-sm.or.id. The Local Education Offices (provincial and regional) propose which schools are to be accredited.

Upon being notified, the schools download and print the instruments of accreditation from http://www.ban-sm.or.id for them to complete the data instruments, supporting information and accreditation instruments. All completed, the documents shall be uploaded through an Application Program at http://www.ban-sm.or.id. Upon receipt of all the required data, BAP-S/M validates them for recommendation of site visits. At this point, there are two possibilities: one is that, if a particular school is not eligible for a site visit, the school will be notified by email; the other is that if a particular school is eligible for a site visit, BAP-S/M will assign assessors to conduct a site visit.

Upon a site visit, BAP-S/M validates and verifies the visit findings for further recommendation. At this point, there are two possibilities: one is that, if the school fails to be accredited, it will be notified by email, on the other hand, if the school is successfully accredited, BAP-S/M will issue a Certificate of Accreditation and report the data to BAN-S/M (National Board of Accreditation for Schools) and other related parties. Finally BAP-S/M will officially announce the results of accreditation to the societies.

The above policies shall accordingly be guided, monitored and evaluated in terms of their implementation in the field. Previously, a survey was conducted nationally by the Ministry of Education of the Republic of Indonesia (2011) assessing the school accreditation system. The overall result indicated that it was ready for implementation. Therefore, the author in support of the Government Policy on School Accreditation conducted the current survey to critically review the school accreditation program implementation framed under two research questions: (1) How is the school accreditation program implemented? (2) What recommendations may be offered for better implementation of the school accreditation program in the future?

\section{Method}

\subsection{Subjects}

The current survey involved Central Java Regions covering 35 regencies from which 1,985 schools were randomly sampled out, assumed to represent the population. The subjects were five School Accreditation Assessors of Provincial Board of School Accreditation (BAP-S/M).

Analysis of the data was performed on basis of item by item description in order to yield thorough profiles of the accreditation program implementation upon which recommendations for betterment could be offered to related parties.

\subsection{Procedures}

The survey was undertaken in three stages: (1) data collection, (2) evaluation and analysis, and (3) mapping. The data were collected through in-depth interviews with the subjects and reviews of official documents in the office of BAP-S/M. In the second stage, the data were analyzed to find out the clear picture of school accreditation program implementation so as to offer possible recommendation. The mapping activities included formulation of recommendation based on the results of analysis and evaluation. In this stage, possible resources were reviewed to find out solution to the existing problem.

\section{Results}

\subsection{In-Depth Interviews}

The result of the interviews with five assessors of BAP-S/M indicated similar opinions. They all agreed that school accreditation is one of the ways of external auditing in support of quality assurance of educational enterprise. Two of them expressed their agreement with the possibility of data engineering in the process of accreditation, namely discrepancies between the data in the accreditation form and the reality in the fields. The other three assessors actually agreed to such practices but wisely commented that being accredited was of primary importance, especially with respect to marketing purposes for the sake of increased or at least sustained students intake year after year. However, they also agreed that there were schools which really deserved to be accredited upon meeting the required standards of school accreditation.

\subsection{School Accreditation}

The number of schools to be accredited in 2013 was of 1,972 schools including Madrasah (MI, MTs), vocational 
schools (SMK), and schools for students with disabilities (SLB) as tabulated below.

Table 1. Accredited schools in central Java

\begin{tabular}{cccccc}
\hline No. & $\begin{array}{c}\text { School } \\
\text { Type }\end{array}$ & $\begin{array}{c}\text { Financed by Religion } \\
\text { Ministry }\end{array}$ & $\begin{array}{c}\text { Provincially } \\
\text { Financed }\end{array}$ & $\begin{array}{c}\text { Regionally } \\
\text { Financed }\end{array}$ & $\begin{array}{c}\text { Locally (by City) } \\
\text { Financed }\end{array}$ \\
\hline 1. & SD/MI & 555 & 550 & 130 & 1,235 \\
2. & SMP/MTs & 250 & 200 & - & 450 \\
3. & SMA/MA & 50 & & & \\
4. & SMK & - & 165 & - & 165 \\
5. & SLB & - & 10 & - & 10 \\
& & 855 & 987 & 130 & 1,972 \\
\hline
\end{tabular}

Table 1 shows that, if compared with the target of 1,985 in $2013,99 \%$ of the schools $(1,972)$ have been accredited. There were 13 schools (SMA/MA) which were not lucky enough to gain accreditation.

In terms of the types of schools under investigation in 35 regencies in Central Java, there were actually 1,985 schools, as tabulated in Table 2 below.

Table 2. Types of schools targeted for accreditation

\begin{tabular}{lll}
\hline No & Types of Schools & Total \\
\hline 1. & Elementary School (SD) & 618 \\
2. & Islam-Based Elementary School (MI) & 617 \\
3. & Junior High School (SMP) & 148 \\
4. & Islam-Based Junior High School (MTs) & 302 \\
5. & Senior High School (SMA) & 45 \\
6. & Islam-Based Senior High School (MA) & 67 \\
7. & Vocational School (SMK) & 165 \\
8. & Schools for students with disability (SLB) & 10 \\
\hline & Total & 1985 \\
\hline
\end{tabular}

In terms of accreditation ranks, the following schools under study have undergone accreditation process with four schools ranked as non-accredited, as shown in Table 3 below.

Table 3. Ranks of accreditation

\begin{tabular}{lllllllllll}
\hline No & Rank & SD & MI & SMP & MTs & SMA & MA & SMK & SLB & Total \\
\hline 1. & A & 212 & 176 & 68 & 68 & 19 & 13 & 50 & 1 & 607 \\
2. & B & 396 & 409 & 66 & 202 & 15 & 42 & 95 & 8 & 1,233 \\
3. & C & 10 & 32 & 14 & 31 & 10 & 13 & 20 & 1 & 131 \\
4. & Non-Accredited & 0 & 0 & 0 & 2 & 0 & 0 & 0 & 0 & 2 \\
\hline Grand Total & 618 & 617 & 148 & 302 & 44 & 68 & 165 & 10 & 1,972 \\
\hline
\end{tabular}

Table 3 shows that Elementary Schools (SD/MI) dominated Rank B of Accreditation. Rank A was dominated by SMP and SMA while MTs, MA, SMK and SLB dominated Rank B. Only very few schools were non-accredited, which might be due to administrative discrepancies. However, it should be noted that both Rank $\mathrm{C}$ and Non-Accredited Rank shall propose for reaccreditation which can be done within three years of the date of the 
accreditation.

\subsection{Profiles of the Accredited Schools}

An accredited school is the one which has both qualified teachers and education administrators (librarians, administrative staff, cleaning and security staff) and is managed by the principal and the vice principals of high quality leadership. Each unit of service is measured against certain criteria. At school levels, there are, as previously mentioned, eight standards that must be fulfilled by any school recommended for accreditation.

\subsubsection{Standard of Contents}

There are nine components of the curriculum (Ministerial regulation for education No. 22/2006). However, some schools manage to perform all, some other only eight, seven, six or even none depending on the capacity of the school in question. As well, the curriculum should be developed in collaboration of several parties such as teachers, counselors, school committee, stakeholders and any other related party. It should also be developed following the mechanism of making a curriculum, which consists of seven, five to six, three to four, or one or two stages of development. The school has to implement the curriculum on the basis of service improvement, empowerment of natural, social and cultural conditions. The inclusion/choice of the local contents in the curriculum have to involve several related parties. The school must also have counseling and extra curricular activities.

More importantly, each lesson in the curriculum must have competency standard and basic competencies which have to be offered for achievement within a particular learning load. The teacher must give the students structured assignments apart from unstructured assignments. Any creation and development must be validated by Local Education Office as it is possible for a teacher to create his or her own syllabus for the lesson. The syllabus has to be constructed according to the guideline. Finally, there must be an academic calendar for all academicians to adopt.

\subsubsection{Standard of Process}

The school develops the syllabus independently (Ministerial regulation for education No. 41/2007) or in any other way based on the standard of contents, the standard of graduate competence as guided by unit-based curriculum development (KTSP). Each lesson has a lesson plan (RPP) generated from the syllabus, there can be thirteen, twelve, nine, or five lessons. The lesson plan is developed, considering the students' individual differences, encouraging the students' self-participation, and employing information technology and communication.

As well, the school undertakes the learning process by fulfilling all the requirements in accordance with learning procedures. The learning process is monitored by the head master (principal) with respect to planning, implementing and evaluating. The principal also supervises the learning process, by providing examples, discussion, training and consultation. Evaluation of the learning process performed by the principal includes learning process and teachers' performance, only learning process or only teachers' performance. The principal reports the results of supervision to the stakeholders. Follow-up activities are undertaken upon feedbacks.

\subsubsection{Standard of Graduate Competence}

The students (Ministerial regulation No. 23/2006) undergo learning experiences to show the ability of thinking logically, creatively, innovatively in decision making with $75 \%$ or $70 \%$ of mastery learning in science and technology. They are also involved in learning process related to analysis and complex problem solving of at least four or three times a year. They are also involved in learning process related to analyzing natural phenomena, such as in physics and natural science. They also have experiences in effective learning process related to science and technology in such as way that all possible learning resources (textbooks, laboratory work) in order for them to get used to finding information elsewhere. The environments shall be made used productively and accountably (by the students). They can express themselves in arts and cultures in a well-designed cultural setting, as well as appreciating the works of arts and cultures. They can develop their self-confidence by means of co-curricular activities in order for them to be able to participate in enforcement of social rules and norms.

Likewise, the students shall develop competitive attitude to get the best by means of rewards for good achievers. They are also trained to participate in the life of the local and national communities in Indonesian scope of democracy. They shall build up their characters and are sensitive to environmental cleanliness to understand and appreciate the rights and responsibilities of and toward other people in the society. They are also brought up in their own religion so as to have good behaviors and affective in nature in appreciation of different races, religions, socio-economic status in a global scope, including to show empathy to other individuals. 
Furthermore, the students shall be able to produce or generate creative works in group or individually and have the ability to use spoken and written language effectively, yet politely as shown in creative, systematic and esthetic text writing and or speaking. In short, they shall be equipped with the mastery of both Indonesian and English for them to develop the science and technology for further education.

\subsubsection{Standard of Teachers and Education Administrators}

The teachers shall (Ministerial regulation for education No. 23/2007) minimally have undergraduate or diploma 4 degrees for them to be able to teach according to their majors of studies and are spiritually and physically healthy to perform teaching tasks. They shall also plan, implement, and evaluate the learning process in accordance with the learning principles. They shall also have personal integrity and therefore act in accordance with the religion, norms and existing regulations. They have to communicate with their colleagues, education administrators, and students' parents effectively, yet politely, such as in meetings or other informal settings. They have to master the lessons they are teaching and to develop within scientific methodology.

The principal shall be certified as a teacher and appointed with a decree as the principal. He or she has a minimum degree of undergraduate or diploma 4 with at least five years of teaching experience. He or she must have managerial skills as shown in how to deal with students. He or she must also have entrepreneurial skills in management of services as the students' learning resource. He or she shall monitor and supervise the learning process.

The administrator(s) shall hold at least a high school diploma, assigned in an appropriate position. A laboratory has at least two personnel with one or both in line with the technical expertise required in the lab. The school must also have at least one personnel for general office services. An employment of security personnel is preferred.

\subsubsection{Standard of Infrastructure}

The area of school premises (Ministerial regulation for education No. 24/2007) must meet the minimal standard, be secured from danger that may threaten health and life of individual, and have access to exit in case of emergency situations. The school must be located in a clear status of land ownership with the area of floors according to specific standards of education; the building(s) must be strong enough, well-constructed against the danger of fire and thunder completed with a legal construction permit, have sufficient sanitary systems, be ventilated for air circulation, and be installed with at least 1,300 watt electricity.

The school must have the minimum requirements of classrooms in terms of total number, size, according to the student body-number. A library must be available as the center of academic resources. Five laboratories - biology, chemistry, physics, computer, language - must be available for use with minimum standards of requirements.

As required by the standard, the principal must occupy a specific room; the teachers must have rooms for lesson preparation, and other administrative work; the administrative staff must also be localized in a specially designed room with easy access for administrative purposes.

The school must have special places of worship, health clinic, counseling and student organization. Toilets must be available in separate places for use by the principal, the teachers and administrative staff, and the students. There must be a warehouse for the school. Finally there must be a place for sport activities.

\subsubsection{Standard of Management}

The school (Ministerial regulation for education No. 19/2007) must have a vision and missions which can be easily comprehensible with specific goals of education, have a long term plan (4 years) broken down into annual plans, have a written guide to regulating a various aspects of management, easily comprehensible to public and related parties, with a clear organizational structure in order for all the personnel to have specific job descriptions.

The school management must perform the organizational tasks as specified in the annual work plan, including students' developmental activities, and developing the curriculum along with the learning activities-all well-documented. The teachers and education administrators must be empowered in their jobs to create conducive learning environments.

The school must cooperate with other related parties or organizations in the management with a program of supervision that has been introduced to the teaching and administrative staff for ease of self-evaluation and performance assessment. 


\subsubsection{Standard of Finance}

The management (Government regulation for education No. 48/2008) must have the documents of values of all school assets, financing the educational activities according to the annual budget plan. The school must have a working capital to finance all the activities for the last one year, including for payment of salaries, incentives, allowance for teachers and administrators. There must be a special allocation of fund in support of learning activities, including the students' extra-curricular activities, purchase of school supplies, academic meeting, formal travels, and duplicating question papers for examination.

The other operational costs include payments of taxes, services, electricity bills, telephone bills, and improvement of welfare. Finally, School fees must be set up in line with the financial stance of the students' parents. The students must also pay the re-registration per semester. Cross-financial subsidy for poor students must also be provided.

\subsubsection{Standard of Evaluation}

Each syllabus (Ministerial regulation for education No. 20/2007) must be completed with or accompanied by evaluation systems, indicators of achievement. The teacher must develop the question papers in accordance with the guide to evaluation. In evaluating the students, the teacher may use several techniques, such as testing, observing and or other means of evaluation. The results of academic and personality evaluation shall be used as a feedback for further improvement, and be reported to the management.

The passing grade for each lesson must be fixed in an academic meeting and be used in both mid and final evaluations to determine whether a particular student can go on to the next level.

Results of overall evaluation shall be reported to the students' parents, and the management shall report the learning achievements to the local education office. Upon completion of all academic and non-academic requirements, each student shall be awarded a certificate of completion issued by the school managements. There are both school and national examinations for SMP/MI, and SMA/MA/SMK.

\section{Discussion and Recommendations}

Despite the fact that schools have been accredited, it does not mean that they can go without any problems. School accreditation process is so 'prepared' and can therefore be so "engineered" that it may not represent the real day-to-day educational operations. For the non-accredited schools, the situations can even be worse. Below is a review of the common school problems.

\subsection{Elementary Schools (SD/MI)}

First of all, administrative staff for the library and special services should be improved. Therefore, recruitment process related to the quality and academic requirement should be more selective, adopting the current standard. As well, the infrastructure, and process quality should be improved toward learning experience in support of the creative, innovative, critical, and logical thinking ability. Secondly, the local government should facilitate the issue of IMB (Certificate of Building Construction) and the school layout should be made in accordance with the technical standards. It is then necessary for the school to reorganize the building layout with particular attention to the mechanism of air circulation in each classroom and office.

Local or school-based curriculum needs to be constructed with the involvement of school committee, education office, and other related parties. The academic calendar should be matched with the real academic activities. Learning activities should be character-based. Some schools should provide additional hours of teaching for students' improvement. Each syllabus must be accompanied by the lesson plan. All teachers should at least hold bachelor degrees. The school should also provide guidance and counseling services for the students. There should be more extra-curricular activities next to boy-scouting.

\subsection{Junior High Schools (SMP/MTs)}

It is high time that the schools increase the qualification of the administrative personnel either by awarding them scholarship for further studies or recruiting new staff of administration. In addition, the quality of the laboratory should be increased in terms of facilities and staff. Recruitment of librarians and laboratory staff is required. The principal must have entrepreneurial spirits. The school must have the certificate of land ownership and permit of building construction.

The curriculum should be generated into syllabi and each syllabus should be elaborated in a lesson plan. Special training is therefore required. Laboratory activities should be done in the laboratory—not in the classrooms. The principal should make follow-up activities based on the evaluation. 


\subsection{Senior High Schools (SMA/MA/SMK)}

The teaching and learning processes should be improve to qualify for the competency standard as set in each syllabus with a particular attention to productive lessons, such as chemistry, biology, physics, English and social sciences (SMA/MA), and vocational competence (SMK). One way to improve educational quality is to upgrade the teachers' qualification, such as letting them to pursuit further studies or special trainings according to the demands for new technology related to teaching methodology — in other words improving their computer literacy to get access to the vast array of information.

All teachers must document all the structured and non-structured assignments. The principal should monitor the students' achievements. The students should be trained how to compete in regional, national and international levels. Libraries should be managed by librarians - not teachers since in reality, teachers whose teaching hours are below the minimum total as required may be assigned as 'librarians' to cover the lack of teaching loads.

\subsection{Schools for Students with Disability}

Several items should be improved, such as teachers' qualifications, facilities, infrastructure, teaching materials, and any other related educational service. This is understandable since SLB is quite few in number and the community seems to be not quite of concern over the existence of schools for students with disability.

\section{Conclusion}

Outlined so far is a quick, yet evaluative review of the implementation of school accreditation program in Indonesia. Despite the subjects taken were of Central Java schools, the results may represent the schools throughout Indonesia. Accreditation process is prepared, and thus the possibility of data engineering is quite high. However, it is still important since a particular accreditation rank can enhance the marketing activities during the annual intake of the students. Academic sincerity is highly priced in Indonesia. Therefore it is highly recommended that each school should offer a tradition of excellence beyond the preparatory period of accreditation process.

Even if a school has been accredited, say with Rank A or B, it does not mean that the school is free from problems. Improvement in all aspects of school operations is still needed; and monitoring/supervising cannot indeed be left out. The best supervision is of self-initiated supervision on the basis of the demands for a long-term sustainability of educational enterprise.

\section{Acknowledgments}

Special sincere gratitude shall go to (1) the Rector of Tidar University of Magelang for the university financial support to conduct this survey (2) the Head and Staff of Research Center Tidar University Magelang for free use of research facilities (3) Prof. Dr. Sukarno, M.Si for his constant guidance and encouragement toward completion of this survey.

\section{References}

Badan Akreditasi Nasional. (2009). Perangkat Akreditasi SMA/MA 2009. Jakarta: Badan Akreditasi Nasional.

Kementrian Pendidikan Nasional. (2006). Permendiknas No. 19/2006. Jakarta: Kementrian Pendidikan Nasional.

Kementrian Pendidikan Nasional. (2006). Permendiknas No. 20/2006. Jakarta: Kementrian Pendidikan Nasional.

Kementrian Pendidikan Nasional. (2006). Permendiknas No. 22/2006. Jakarta: Kementrian Pendidikan Nasional.

Kementrian Pendidikan Nasional. (2006). Permendiknas No. 23/2006. Jakarta: Kementrian Pendidikan Nasional.

Kementrian Pendidikan Nasional. (2006). Permendiknas No. 24/2006. Jakarta: Kementrian Pendidikan Nasional.

Kementrian Pendidikan Nasional. (2006). Permendiknas No. 41/2006. Jakarta: Kementrian Pendidikan Nasional.

Kementrian Pendidikan Nasional. (2011). Analisis Sistem Akreditasi Sekolah dan Madrasah. Jakarta: kementrian Pendidikan Nasional. Retrieved from http://www.dikti.go.id/files/atur/rbi/AkreditasiSekolahMadrasah.pdf

Pemerintah Propinsi Jawa Tengah. (2013). Peraturan Gubernur Jawa Tengah No. 8/2013 tentang Badan Akreditasi Propinsi Sekolah/Madrasah tingkat Propinsi Jawa Tengah Tahun 3013-2018. Semarang: Pemerintah Propinsi Jawa Tengan.

Pemerintah Propinsi Jawa Tengah. (2013). Surat Keputusan Gubernur Jawa Tengah No. 420/23/2013 tentang Badan Akreditasi Propinsi Sekolah/Madrasah tingkat Propinsi Jawa Tengah Tahun 3013-2018. Semarang: Pemerintah Propinsi Jawa Tengan.

Pemerintah Republik Indonesia. (1945). Undang-Undang Dasar Negara Republik Indonesia 1945, Pasal 31, 
Ayat 2. Jakarta: Pemerintah Republik Indonesia.

Pemerintah Republik Indonesia. (2003). Undang-Undang No 20/2003 tentang Sistem Pendidikan Nasional. Jakarta: Pemerintah Republik Indonesia.

Pemerintah Republik Indonesia. (2005). Peraturan Pemerintah No. 19/2008 tentang Standar Pendidkan Nasional (SNI). Jakarta: Pemerintah Republik Indonesia.

Pemerintah Republik Indonesia. (2006). Peraturan Pemerintah No. 11/2008 tentang Pendidikan. Jakarta: Pemerintah Republik Indonesia.

Pemerintah Republik Indonesia. (2008). Peraturan Pemerintah No. 48/2008. Jakarta: Pemerintah Republik Indonesia.

United Nations General Assembly. (2002). A World Fit for Children on Protection of Children against Torture and Exploitation. Retrieved from http://www.unicef.org/specialsession/docs_new/documents/A-RES-S27-2E.pdf

United Nations Organization. (2000). Millennium Development Goals. Retrieved from http://www.undp.or.id/pubs/docs/Let\%20Speak\%20Out\%20for\%20MDGs\%20-\%20ID.pdf

\section{Note}

Note 1. Including Islam-based and vocational schools $(\mathrm{MI}=\mathrm{SD}, \mathrm{MTs}=\mathrm{SMP}$ and $\mathrm{MA}=\mathrm{SMA}=\mathrm{SMK})$.

\section{Copyrights}

Copyright for this article is retained by the author(s), with first publication rights granted to the journal.

This is an open-access article distributed under the terms and conditions of the Creative Commons Attribution license (http://creativecommons.org/licenses/by/3.0/). 